\title{
Museums, Memory, and the Just Nation in Post-Civil War EI Salvador
}

Robin DeLugan*

\begin{abstract}
In 1992 El Salvador ended a 12-year civil war infamous in part for the high level of state violence against innocent civilians. A United Nations Truth Commission report, which detailed these and other excesses, recommended that state and society commemorate the war and its violence to advance the establishment of a more just nation. The postwar government did construct an impressive new National Museum of Anthropology to actively promote national culture, history, and identity. However, this important museum remains silent about the civil war. In contrast, new public - though not official - museums and monuments are finally bringing attention to the civil war and past state violence. This paper explores the social memory work of non-official museums, arguing that by combating silence and forgetting, their truth-telling aims to shape ideas about the nation and improve state-society dynamics.
\end{abstract}

Key words: Nation-state, state violence, memory, justice

All nations are anchored to a past. The ability of state-sponsored museums to shape dominant understandings about the nation and its history is now well established (Anderson 1993; Bennett 1995; Boswell and Evans 1999). In addition, because national museums are often housed in majestic architecture, museum visitation can be an awe-inspiring experience for citizens that some scholars liken to ritual (Duncan and Wallach 1980). When such museums, functioning as a technology of the state, coordinate their meaning-making policies and practices with other government educational and cultural entities, powerful representations of the nation are asserted and reinforced. Despite their ability to exhibit hegemonic definitions about national belonging, official national museums can and do exclude. In particular, they can be silent about a nation's bleak history of past state repression and violence.

Oleaga et al. (2011) argue that access to history and memory is a fundamental right, one that affects national identity and citizenship. Recognizing that museums do important identity work by showcasing significant objects and demonstrating that the nation has a history, these scholars ask whether museums in the twenty-first century can do more to provide accounts that address anti-racism, inclusion, and belonging. To this I would add the importance of museums providing accounts of past state violence, dictatorship, and repression. When national museums, in particular, avoid difficult pasts, society is deprived of an honest reflection on the nation's development. This can impede efforts to create a more just, inclusive, and democratic future.

In the introduction to Museums and Memory, Susan Crane describes museums as sites of history and memory 'where subjectivities and objectivities collide' (2000:7). The 'collision' can involve a difference between history and memory. The relationship between the two is often articulated as a relationship of power, where history represents the 'official' past so important in legitimating nation-state power, and memory represents other understandings that may contrast with or contest the official version. Over the past few decades, public (though not necessarily official) museums have transformed into important forums for addressing gaps between history and memory by integrating new voices and experiences, inspiring public discussion and debate, and grappling with controversial topics (MacDonald and Fyfe 1996: 3-19). Whether addressing multicultural or subaltern histories or other equity concerns, some 
new museums aim to be advocates of social justice, inclusion, and democratization. Unofficial museums, though disengaged from the state power that defines 'the official', nonetheless have the ability to influence popular understandings of the nation's past and present. As sites of memory, museums may bring attention to difficult episodes and conditions about which the government is silent. As such, museums can be important places for recognizing strategies of domination as well as acts of resistance, and thus can be important sites for national reconciliation in the aftermath of civil conflict.

Louise Purbrick (2011) argues that there is a strong connection today between the truth telling ability of museums and human rights discourse and action:

The invocation of human rights in museums... is an extent to which their principles have become a measure through which the past is interpreted; the deployment of a discourse of human rights to indict the past is a shared strategy that has assigned to museums a role in historical reparations. (186)

Museums can evoke human rights by referencing their ideals, but this can also mean confronting the dire circumstances of human rights violation or abuse. Discussing museum exhibitions that tackle difficult topics, Bonnell and Simon (2007) ask what can be achieved by making painful memories public: difficult exhibitions can bring forward feelings of grief, anger, shame, horror, frustration, guilt, and even complicity. Despite arguments for not bringing troublesome pasts into the present, all reflection on the past is also about the present moment and future aspirations, and museums that address a nation's history of state violence and human rights abuse can thereby demonstrate what international entities such as the United Nations refer to as the moral obligation to improve both state and society in the aftermath of atrocity.

[There are] ways which public history might animate a critical consciousness, a way of living with and within history as a never-ending question that constantly probes the adequacy of the ethical character and social arrangements of daily life. (Bonnell and Simon, 2007: 65)

Though we can observe a contemporary trend of museums and other heritage sites addressing past episodes of state violence and atrocity by also promoting human rights, it must be underscored that difficult episodes from history can often be highly contested. Logan and Reeves' (2009) cross-cultural study of museums and other heritage sites examines such contestability, in particular as it is expressed through the intersection of political and heritage agendas. Contestability is especially common when dealing with the aftermath of civil war, which is often motivated by conflicting and polarizing political ideologies that divide a national society, and it is also prevalent in other national struggles such as the aftermath of authoritarianism and dictatorship.

In South America, late twentieth century nation-state transitions from authoritarianism and dictatorship have inspired foundational scholarship on the memory of state violence in relation to transitions to democracy and the promotion of human rights, including the role of museums, commemorative sites and practices, and their challenges (see for example, L. Roniger and M. Sznajder 1999; E. Jelin 1994, 2002; M.J. Lazzara 2003; M. Gomez-Barris 2008, A. Ros 2012, A. Estefane 2013, among others). The authors contributing to The Memory of State Terrorism in the Southern Cone: Argentina, Chile and Uruguay (Lessa and Druiolle, eds. 2011) illustrate how, despite common histories of state violence and dictatorship that link these three nations, each present-day society has a unique perspective on the national politics and practices of memory in regard to this experience.

In Argentina, there have been continuous civil society efforts to keep public memory focused on the 'Dirty War', the military dictatorship campaign from 1976-1983 against suspected left-wing opponents, wherein an estimated 10,000-30,000 were killed-with many 'disappeared'. A proliferation of memory sites includes transforming former detention and torture centers into museum-like spaces (see as example Ex-ESMA). ${ }^{1}$ In 2005 the amnesty laws that protected perpetrators of state violence were deemed unconstitutional. Still, examining the understandings that the younger generation have about Argentina's 'Dirty War' reveals divided opinion. Some who find justification in the state violence share the politics of their parents and grandparents (Kaiser 2005: 23-42). 
Francesca Lessa (2011), in writing about Uruguay, describes the presidential campaign slogan of Julio María Sanguinetti (President 1985-90; 1995-2000): 'No hay que tener los ojos in la nuca/You should not have eyes at the back of your head', which promoted a message that the nation should look forward and not look at the repressive state regime that repressed and tortured citizens from 1973 - 1985. However, in 2007 the government opened the Centro Cultural Museo de la Memoria/Cultural Center Museum of Memory in the capital Montevideo to acknowledge the state's responsibility for years of terror and to 'promote in participatory form peace, human rights, and the memory of popular struggles for freedom, democracy and social justice' (http://www.montevideo.gub.uy/ciudad/cultura/museos-y-salas/centro-cultural-ymuseo-de-la-memoria). These changes in policy and practice illustrate that there is a dynamic process at work regarding when and how to pursue the memory of past atrocities.

In 2010 the Chilean government opened the Museo de la Memoria y Derechos Humanos/ Museum of Memory and Human Rights in the capitol Santiago to address the military dictatorship of 1973-90, a regime that left over 3,000 dead or missing and forced an estimated 200,000 into exile, not to mention profoundly shaping the national political, economic and social life. While some trials have occurred in Chile, most notably that of former General Pinochet, there are ongoing efforts to revoke amnesty laws that continue in place.

Guatemala, a Central American neighbor to El Salvador, endured a 36-year civil war (19601996), during which up to 200,000 people died or went missing, including $40,00-50,000$ who were 'disappeared' largely through a campaign of state violence against citizens. The majority of the victims were Maya Indians. Recently, on 24 February 2014, La Casa de la Memoria Kaji Tulam²/The House of Memory So as Not to Forget was inaugurated in the Guatemalan capital. This museum opening occurred while the historic trial of General Efraín Ríos-Montt, charged with committing genocide during the war, lurched forward and backward through the Guatemala judicial system. And just as the new museum opened, local newspapers reported that another proposed museum, Museo Maya de las Americas/Maya Museum of the Americas-also planned for the capital, Guatemala City--was being contested by Maya Indians who had not been participants in the museum planning process. Their concerns included the idea of a museum being about them without their consultation; how the Maya would be represented through time; the public-private nature of the museum that enlists national patrimony; the location of the museum in a wealthy neighborhood; and the construction of the museum displacing a traditional Maya market (Mallonee 2014a). Yet another concern might be the extent to which the new museum, which is designed to encourage tourism, would represent colonization and state violence, including the genocide of the recent civil war.

While museum exhibitions may foster empathy for and understanding of others, when the topic is state violence and its excesses, they may also elicit the core concepts of citizenship and belonging. When museums and their exhibitions examine the national past and bravely challenge official silence to recall episodes of past state violence, I argue that not only might they advocate for human rights, but they could also make a contribution to nation-building, to the ongoing process of generating shared understandings about what it means to belong to the nation, and in particular, to improving the quality of state-citizen dynamics.

One way this can happen is through the role of museums as public spaces. Jennifer Barrett (2011), reworking Habermas' concept of the 'cultural public sphere', examines how museums as institutions of the public sphere have the potential to incorporate more democratic principles and relationships in their practices. I argue that a museum, in conjunction with other social actors, sites, and practices that actively represent the nation, has the ability to influence state culture and statecraft. Still, there can be a tension when museums function simultaneously as a voice of the state and as a public space for opinion and meaning-making. Exploring how official museums in Canada are re-examining their connection to the public sphere, Susan Ashley (2005) indicates that some museums are moving towards non-authoritative representations and more inclusive participation. This is a positive direction that suggests the democratization of official museums. However, will museums elsewhere be willing to break silence and tackle the difficult topic of past state violence that can bring the very legitimacy of the state into question?

As suggested, for nations that are emerging from dictatorship, state repression, or civil conflict, an important role exists for the museum as memory-keeper and memory-maker 
(Williams 2007). In July 2001, the International Council of Museums (ICOM) established the International Committee of Memorial Museums in Remembrance of the Victims of Public Crimes (ICMEMO).

The purpose of these Memorial Museums is to commemorate victims of State, socially determined and ideologically motivated crimes. The institutions are frequently located at the original historical sites, or at places chosen by survivors of such crimes for the purposes of commemoration. They seek to convey information about historical events in a way which retains a historical perspective while also making strong links to the present. ${ }^{3}$

Inclusion in ICMEMO's international network can give crucial legitimacy and recognition to museums in nations where states are less willing to grapple with past state violence. Another international network, 'Sites of Conscience', is more explicit about the link between museums (and other sites of memory) in the service of civic action and the defense of human rights:

The International Coalition of Sites of Conscience is the only worldwide network dedicated to transforming places that preservethe past into dynamic spaces that promote civic action on today's struggles for human rights and justice. 4

Through public sites of history and memory, this organization and its participating members tackle a range of difficult topics including post-conflict rebuilding. 'Memorial museums' and 'sites of conscience' are illustrative of the potential of museums to be truth-tellers, human rights defenders, and advocates for just and inclusive societies.

My research explores the role of museums in El Salvador's ongoing process of postcivil war nation-building. Drawing on this research, I will illustrate how, in contrast to official silence, two museums are now bringing attention to past state violence associated with the nation's civil war. In the aftermath of El Salvador's 12-year civil war (1980-1992), several new museums have emerged. The investment in the construction of new museums in this economically marginal country speaks to the confidence that certain social actors have in the ability of museums to help shape common understandings about what it means to belong to the nation. Just as Benedict Anderson (1985) and others have demonstrated the historical role of museums in the building of new nations, my research confirms that museums, both official and non-official, have a role to play in the processes by which the post-civil war nation is reconstructed.

The arrival of new museums in San Salvador, El Salvador's capital, paralleled other government-sponsored polices and practices striving to bring attention to national culture, history, and identity (DeLugan 2012: 105-124 ). For example, a new two-volume national history textbook was published for use in many levels of public education; and the nation's first university programs in history and anthropology were established at the national university, Universidad de El Salvador. In the capital, the government built a majestic new National Museum of Anthropology. This museum examines national culture and history by tracing $\mathrm{El}$ Salvador's pre-Columbian cultures, colonial era, and present day society. While an impressive site for communicating a sense of national history and identity, the museum is silent about the civil war, state violence against civilians, or the deeper history of twentieth century dictatorship and repression. In the postwar period, three other privately funded public museums have also appeared in the capital. The sophisticated Museo Universitaria de Antropológia in the Universidad Tecnológica focuses on pre-Columbian roots but also considers the present-day phenomena of mass emigration and the precarious journey that characterizes the experience of many Salvadorans seeking economic survival in new lands. The impressive Museo de Arte (MARTE) houses the largest collection of contemporary works by Salvadoran artists, making it El Salvador's de facto national museum of modern art. MARTE's permanent exhibition is focused on Salvadoran identity. Finally, the courageous Museo de la Palabra y el Imagen (Museum of the Word and the Image), (hereafter MUPI), was created with the explicit mission to remember the civil war, including its atrocities. MUPI is a member of ICMEMO and the International Coalition of Sites of Conscience. My ethnographic research has intently followed the establishment of these museums. I visit the museums regularly and have interviewed their 
key personnel. Before I share more details about postwar public memory sites, let me provide some background context.

\section{A Nation Emerging From War}

In January 1992 the peace accords were signed that ended El Salvador's 12-year civil war. This civil conflict drew international attention, in part for the many atrocities that had occurred. More than 70, 000 civilians lost their lives to state violence that included torture and disappearances. Among these horrific acts was the nearly complete elimination of the population of El Mozote, a rural village in an area that was dominated by the guerrillas. Archbishop Monseñor Romero, a staunch advocate for peace, was assassinated while he officiated at a church mass, and a group of Jesuit intellectuals affiliated with the Universidad Centroamericana and members of their staff were brutally murdered. In the wake of international community outrage, the United Nations (UN) intervened and performed a key role in stopping the violence and ending the civil war. They sent peacekeeping troops, marking the first time that such an intervention was permitted in a domestic conflict. The UN also facilitated the negotiations that ended the prolonged conflict. A UN Truth Commission was established to document civil war atrocities. The report that followed, From Madness to Hope: The Twelve-Year Civil War in El Salvador (UN Security Council 1993), examined 15 cases of extra-judicial assassination, murder, or disappearance allegedly committed by government forces, including five cases of murder by death squads. While the commission also examined violence attributed to the Farabundo Martí National Liberation Front (FMLN), the guerrilla faction, the report determined that 85 per cent of the atrocities were committed by entities allied with state forces. The report was extremely important for documenting the human rights abuses that shook national society to its core. In the concluding comments of the Truth Commission's Report, under the category 'Moral Reparation', the following actions were deemed essential for national reconciliation:

1. The construction of a national monument bearing the names of all victims.

2. Recognition of the good names of the victims and the serious crimes of which they were victims.

3. The institution of a national holiday to memorialize of the victims of the conflict and to serve as a symbol of national reconciliation. [14b: Steps toward reconciliation: Moral compensation]

These recommendations highlight the importance of social memory for national reconciliation and the state engaging in truth-telling about its human rights abuses. In general, until now, the government of El Salvador has not followed through on these recommendations. In fact, between 1989-2009 the government led by the conservative political party ARENA failed to acknowledge that the state or the armed forces had responsibility for human rights abuses. However, since the 2009 election of president Mauricio Funes of the progressive FMLN party, there has been a shift: in 2010 Funes made a series of historic apologies for past episodes of state violence in the name of the government of El Salvador, and he created a national commission to search for children who disappeared during the war. In 2010 there was also a proposal to establish a presidential program for reparations to victims of grave human rights violations (Barahona et al. 2012), but to date this presidential program has still not materialized. Though the government has thus failed to follow through on the recommendations of the UN Truth Commission, it is nonetheless important to recognize the significance of recent government acts. By acknowledging state violence and human rights abuses during the civil war, they have begun to confront El Salvador's bleak history, although they have still fallen short of creating public sites of memory for national commemoration, moral compensation, or social justice. In the absence of official action, civil society actors in El Salvador have slowly taken up the task of creating new museums and monuments to perform a critical function: providing public sites of history, memory, and commemoration.

The Monumento a la Memoria y la Verdad (The Monument to the Memory and the Truth) was inaugurated in December 2003. Erected in Parque Cuzcatlán in the capital, San Salvador, the monument is composed of an 85 meter black granite wall etched with the names 
of more than 25,000 civilian victims (illustration 1 ). ${ }^{5}$ Another portion of the monument contains colorful stucco reliefs in the typical aesthetic style of El Salvador, which depict daily life as well as images of past struggle and violence (see illustration 2).

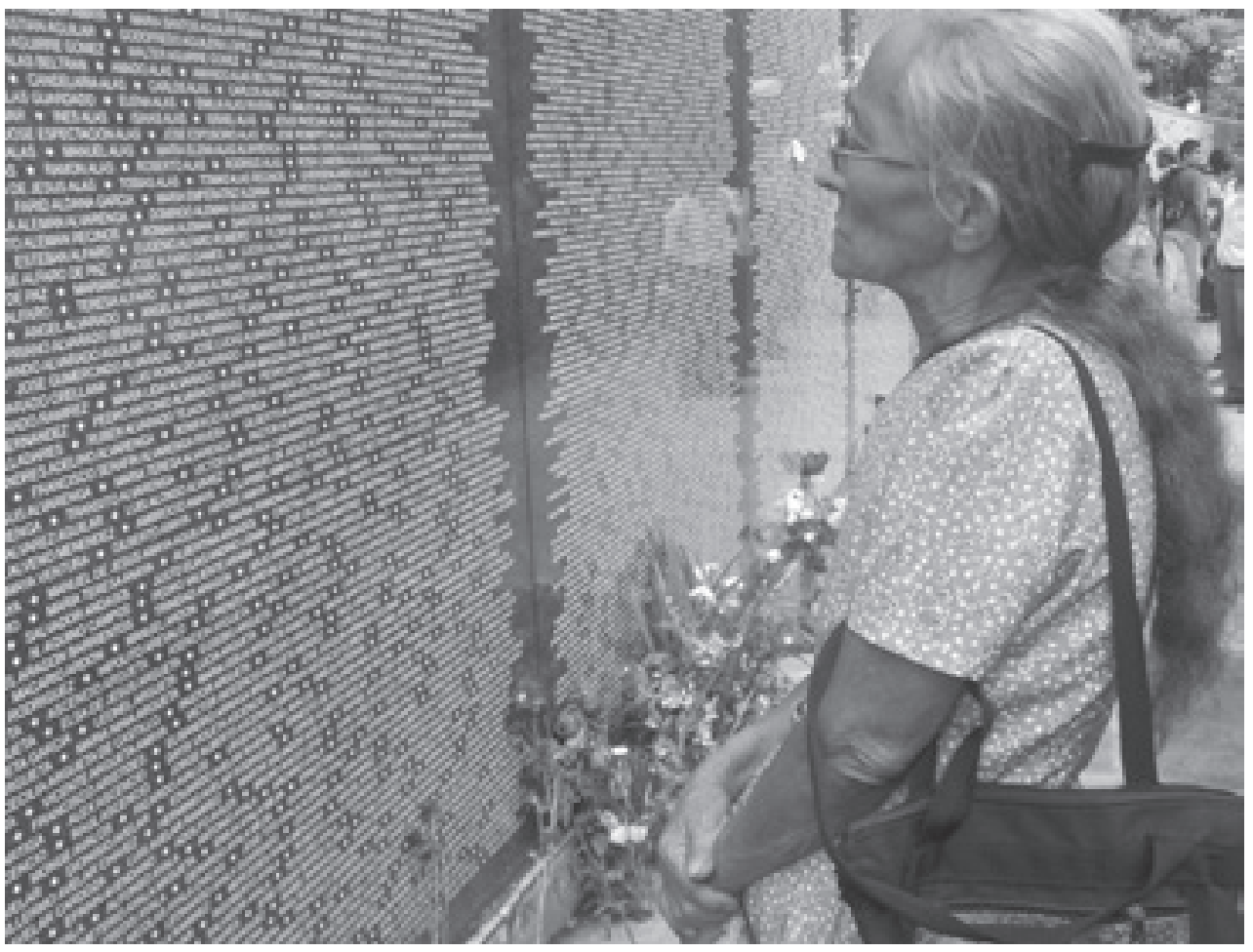

Illustration 1: Monumento a la Memoria y la Verdad (fragment) Monica Barahona

\section{Museo de la Palabra y el Imagen (MUPI): Tejiendo la Memoria/Weaving Memory}

MUPI is a non-profit organization located in the heart of San Salvador, El Salvador's capital. With its motto 'weaving memory,' the museum is dedicated to 'researching, rescuing, preserving and showing to the public elements of the culture and history of El Salvador'. As the name suggests, the museum collects and exhibits photographs, manuscripts, audio recordings, and film. In the years that I have conducted research in EI Salvador, MUPI has moved twice, each time locating the museum in neighborhood settings (see Illustration 3.)

Among the collections in the museum archives are photographs of the El Mozote Massacre (December 10-12, 1981) in which the government's armed forces attacked a rural community and killed more than 800 civilian men, women, children and elders; posters demonstrating the international solidarity for the people of EI Salvador and their revolutionary struggle; posters used by the Salvadoran government's armed forces to reduce popular support for the guerrillas; photos about women combatants; artifacts remembering the popular schools that were activated in the conflict zones during the war; and displays dramatizing the issue of refugees and their return at the end of the civil war. From around the world, MUPI has received manuscripts, printed works, photos, and other materials that represent arguably the most comprehensive archive of the El Salvador civil war.

MUPI's director Carlos Henriquez Consalvi is committed to the goal of the museum as truth-teller and defender of human rights. For this he is well-known and respected in El Salvador and internationally. That MUPI exists in EI Salvador speaks volumes about the nation's progress towards democratization. El Salvador's past repressive governments would probably not have 


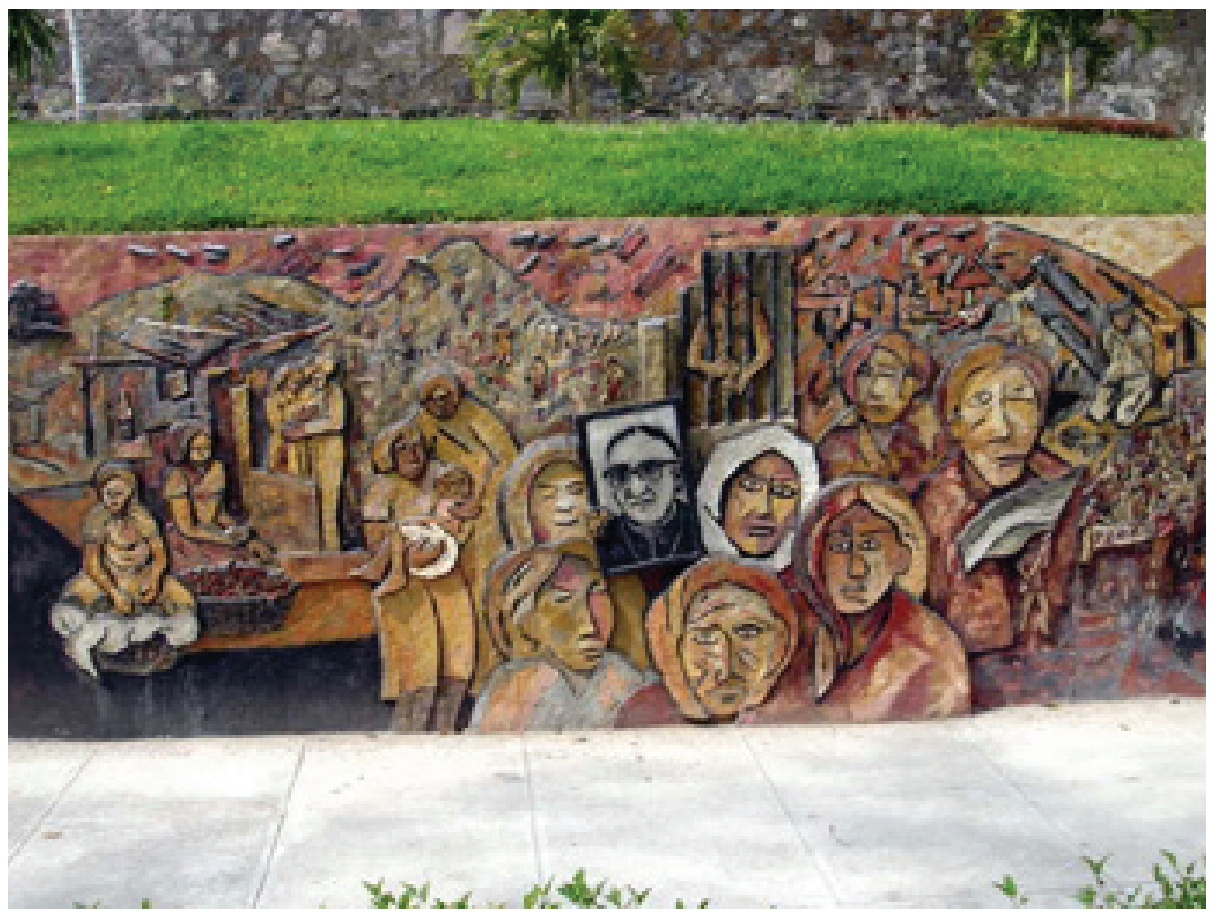

Illustration 2: Monumento a la Memoria y la Verdad (fragment)The message engraved on the Monument to the Memory and Truth is 'a space for hope, to continue dreaming, and to construct a more just, human, and equitable society. ${ }^{\prime 6}$ Among the non-governmental, civil society actors who participated in the construction of this public postwar monument are personnel also responsible for creating and administering the unique museum MUPI.

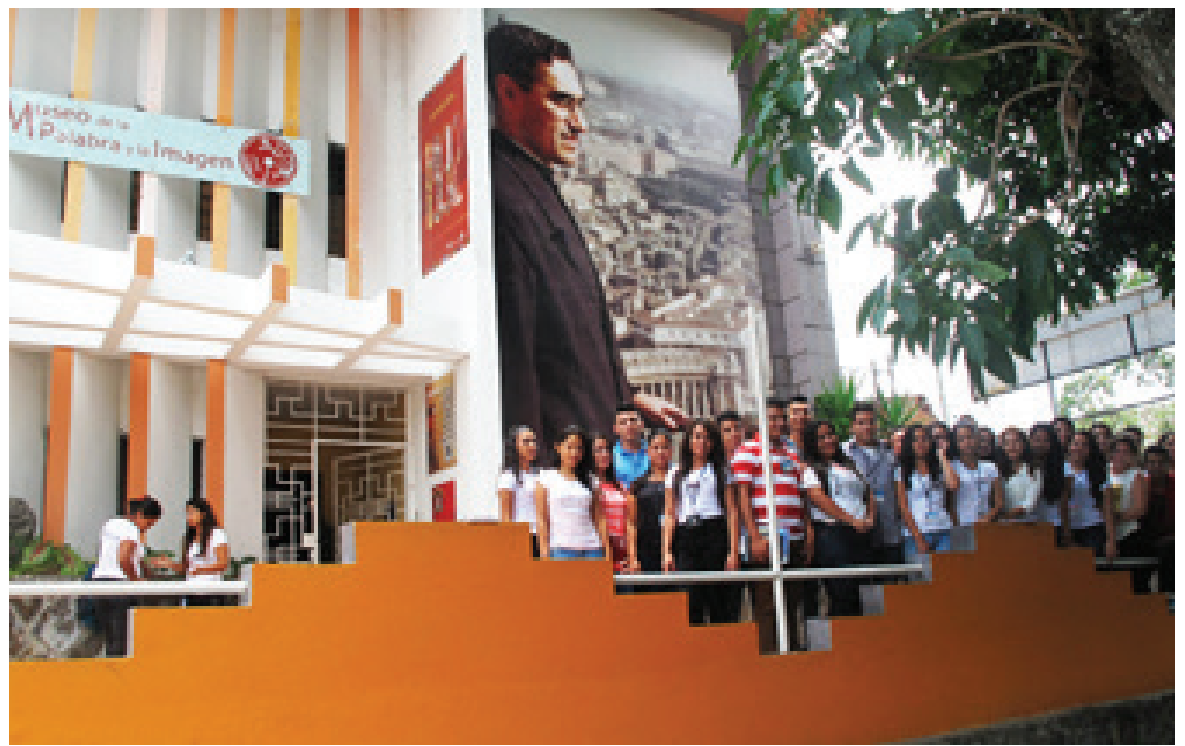

Illustration 3. Museo de la Palabra y el Imagen (exterior) 
tolerated such a forthright critique of state power and representation of popular struggle. As mentioned regarding the Monument to the History and Truth, MUPI and its directors routinely partner with other civil society actors working to protect and defend human rights. MUPI does important memory work to keep El Salvador's difficult past from sliding into public oblivion. On multiple occasions, Consalvi has reiterated to me the vision that the museum be a leading citizen initiative dedicated to the creation and preservation of historical memory: "We believe that in postwar El Salvador, historical memory is needed to shape the future of the just and equitable society we all want'. ${ }^{7}$

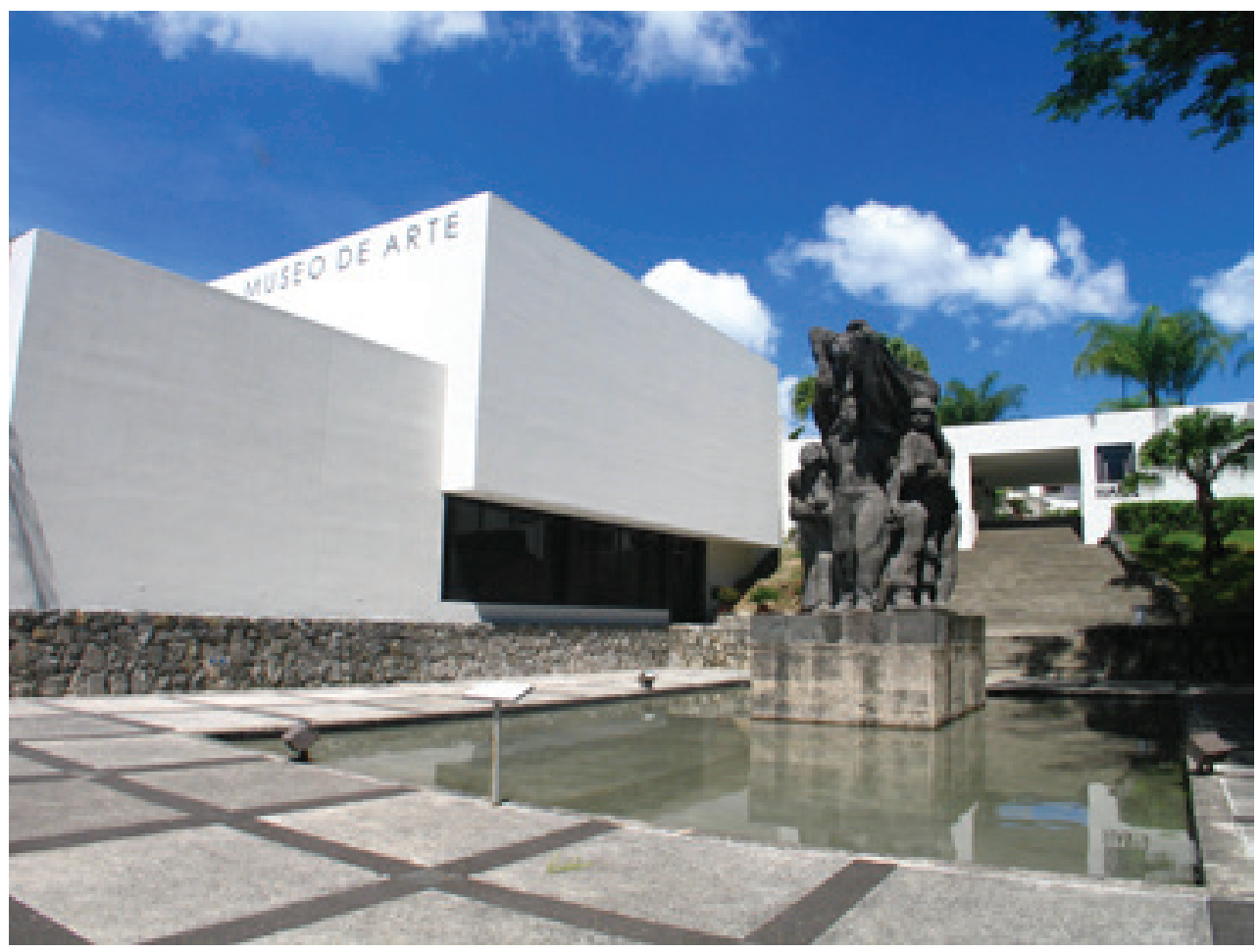

Illustration 4. Façade Museo del Arte (MARTE)

\section{Museo de Arte (MARTE): Una Mirada no Basta.../One Look is Not Enough...}

The elegant Museum of Art (MARTE) was opened to the public in 2003 in San Salvador. This privately-funded museum is architecturally stunning and adds much to the cultural life of El Salvador (see illustration 4). By promoting and supporting contemporary art, it provides further evidence of the growing public investment in national culture. MARTE has an extensive collection of art produced by Salvadoran artists. The collection showcases the country's art history in remarkable depth. Although MARTE is a non-governmental entity, no comparable government-sponsored, official art museum exists. MARTE, therefore serves as the de facto national museum of art

MARTE's collections display some of the best-known paintings by El Salvador's most distinguished artists. To see these paintings carefully organized by theme and style allows the visitor to become more familiar with the high quality of national artistic production. In the large permanent exhibition Trozos de la Identidad (Fragments of Identity), paintings are arranged 'historically, maintaining stylistic and thematic relations along the route to tell the story of our people and our country reflected in art' (author's translation). ${ }^{8}$

Fragments of Identity includes works from 1968 forward. What caught my attention was 
how some of the paintings selected represent social movements, struggle, and the violence associated with the civil war. Among them is El Sumpul by Carlos Cañas (see illustration 5). The abstract painting depicts mass bodies piled on top of one another. The painting refers to a 1980 military operation in which at least 300 civilians (including women and children) were assassinated in the River Sumpul in the department of Chalatenango. By including El Sumpul in the paintings selected to represent aspects of national identity, MARTE does more than display the historical and contemporary artistic talent of El Salvador. It also tells the history of the nation, including its darkest hours. This is to say that the museum serves as an important guardian of memory. For those unfamiliar with national history, the museum is a memory-maker. A new temporary exhibit Moments of Change: the impact of the armed conflict 1980-1992 makes explicit MARTE's attention to memory work surrounding the nation's violent civil war (see illustration 6). As such, MARTE illustrates the museum's ability to bring public attention to the difficult topic of civil war, and in particular, to the topic of state violence.

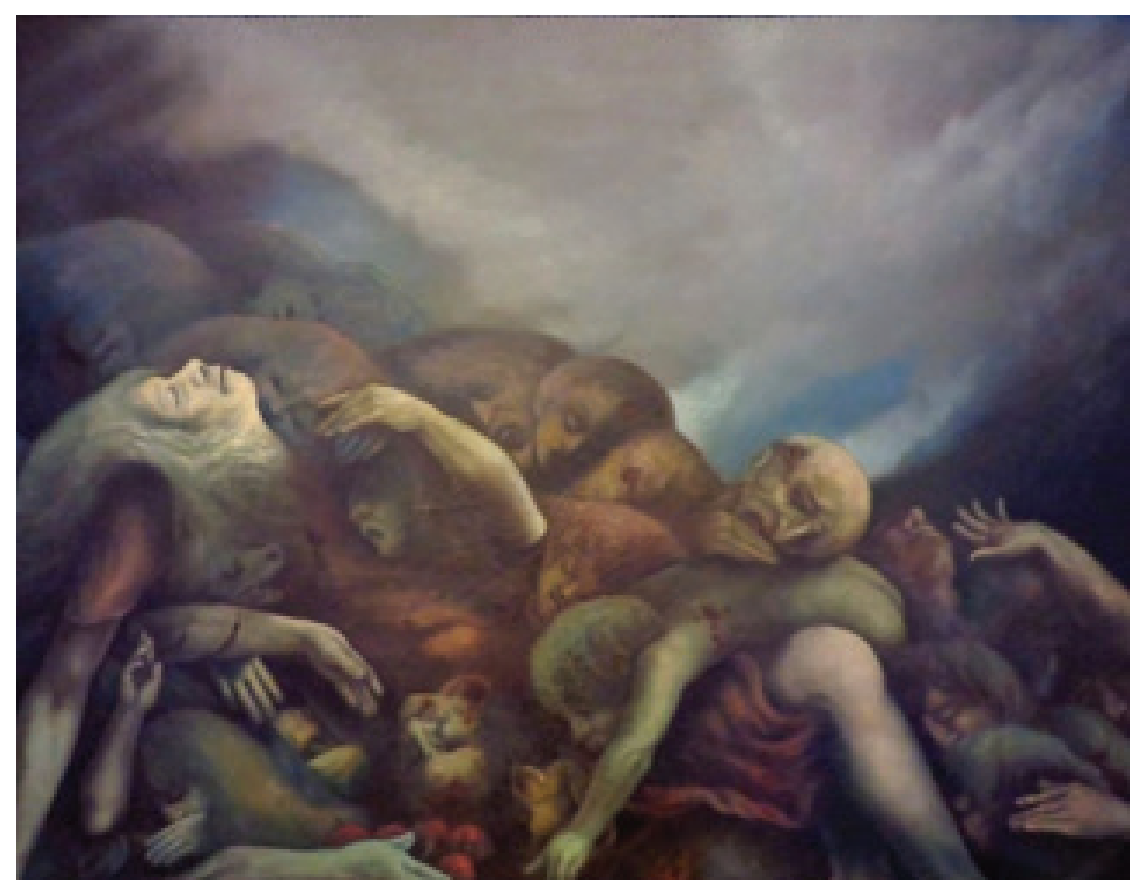

Illustration 5. El Sumpul, 1984 Oil on canvas, 112 x $144 \mathrm{~cm}$. Carlos Cañas (1924) Collection Museo de Arte de El Salvador (MARTE) Image courtesy of MARTE

MARTE's current motto is 'one look is not enough'. This motto can be read as encouraging multiple museum visits, as well a reminder to guests that the museum's extensive offerings merit more interest and attention than a single visit can provide. In light of my research, I read the motto another way. In the context of official public silence and absence of representation about El Salvador's civil war, 'one look is not enough' is a call for more sustained attention to this important and unfinished chapter of the nation's history and democratization. While the museum exhibitions include paintings that deal with tragedies of the armed conflict, MARTE's director Roberto Galicia, himself a painter whose own artwork incorporates themes from the violence of war, sees the goals of the museum foremost as making a significant contribution to the development of visual arts, stimulating creativity and dialogue, and facilitating the search for new horizons of Salvadoran art. ${ }^{9}$ Rafael Alas Vázquez, the museum's program coordinator, recognizes that the museum touches upon political issues that have not been systematically addressed before in the history of Salvadoran arts (Mallonee 2014b). 


\section{Silence, Forgetting, and the Just Nation}

My research has followed over time the appearance of new museums and monuments in El Salvador that address state violence and civil war, understanding their role as important sites of social memory and of civil society's efforts to grapple with the nation's difficult past. In contrast, however, I note the silence of government policies and practices in that regard. While we can ask why might it be important to remember, might it be easier for the nation to forget?

EI Salvador's 12-year civil war ended nearly 25 years ago. Immediately after the release of the UN Truth Commission's report that detailed military and other atrocities, the government passed a general amnesty law. Amnesty would be applied to state actors who were recognized as committing the majority of the atrocities, but also to members of the revolutionary guerrilla forces. This meant no criminal or human rights abuse investigations or charges would be forthcoming. The rationale behind the amnesty agreement was that by relegating the atrocities committed to the past, it would facilitate national reconciliation. Certainly, immediately following the peace accords, passions that fueled the civil war antagonisms were still strong. Society was extremely polarized, and the many levels of war wounds were tender. It may be understandable, therefore, that some social actors sought to avoid the inflammatory issue of civil war atrocities. It must be considered, however, how the issue of amnesty influences the government's continued reticence to recognize the civil war and acknowledge in particular the state violence that occurred against its citizens.

Policies of amnesty are intended to be what Ross Poole (2009) refers to as 'acts of oblivion'. However, Poole and other scholars challenge any automatic link between amnesty and amnesia (forgetting) or oblivion (consider the word 'oblivious'). He reminds us of the paradox of remembering and forgetting: we cannot forget something that we do not remember. Amnesty's charge to 'forget', therefore, simply reminds us of that which is to be forgotten. Still there can occur a process that connects memory, forgetting, and oblivion in stages, wherein reaching oblivion means something no longer exists in memory or awareness.

In El Salvador, government policies of amnesty may attempt to further a politics of forgetting and eventual oblivion. Even without an explicit command to forget, the amnesty law gives permission to the state to withhold from public reflection that difficult past which amnesty is designed to protect. My research argues that omission of El Salvador's civil war from museums and other state technologies that shape understandings of national history and identity is further reinforced by the absence of acts to commemorate the victims of the civil war. However, in line with the paradox of remembering and forgetting, while amnesty is meant to remove past atrocities from present day concern, what it does instead is offer a reminder that wrongs were committed and that justice was interrupted: the very definition of amnesty. Still, we can be concerned that amnesty and the disruption of justice contribute to official silence that over time may foster oblivion.

Many scholars have theorized about the dynamics of memory, silence, forgetting, and amnesty, particularly in the aftermath of painful national experiences. By linking memory and forgetting, Bradford Vivian (2010) asserts that there may be conditions where public forgetting can allow a new beginning. Memory and forgetting are interconnected in the 'densely interwoven dimensions of larger symbolic or discursive processes' (10). In his analysis, forgetting is not equated with a desire to not remember, but with a tacit agreement to not focus on a difficult past that may impede a path forward. Examining the link between memory and forgetting in the context of mass genocide and other human atrocities, Paul Ricoeur (2004: 457-500) considers the connection between 'amnesty' and 'amnesia'. He posits that it is through mourning, but also forgiveness, that the boundary between amnesty and amnesia is preserved. His prescription is to commemorate and forgive, but not forget. Luisa Passerini (2006) posits that the body itself remembers and that silence and the unspoken may still contain memory. Addressing Ricouer's idea that there can be 'amnesty without amnesia', she counters that mourning and forgiveness do involve a type of forgetting, 'understood not as silence but as a statement in a pacified mood, without anger-an enunciation to be understood not as a commandment, but as a wish' (Passerini 2005).

For those constructing public sites of memory about El Salvador's civil war, the wish of many is for a more just nation. We can debate the definition of a just nation. El Salvador is 
a newly democratizing nation-state with a long experience of mass poverty, grave inequality, military dictatorship and repression, state-sanctioned racism, and impunity for government leaders or other perpetrators of atrocity. It is easy to imagine that a 'just nation' in contrast would be more equitable, more democratic, and more inclusive. In addressing the difficult past, forgiveness, in particular as a Christian virtue, may suffice for some. For others, a just nation will require improving trust between citizens and the state. This is evidenced by ongoing action to challenge the amnesty law's suspension of justice. ${ }^{8}$ Meanwhile,public (though not official) museums and monuments strive to preserve memory against the forces that can lead to forgetting or oblivion.

Contained in the politics of memory are aspirations for the future. Memory is never only about the past, but about the present-day motivation for recalling the past. This points to the temporality of memory and memory's role in the present, especially its role in constructing the future. Past events, including atrocities, may be motivated by a particular vision of the future, such as goals for the nation. When memory later recalls that event, it is the presentday context, including expectations and goals for the future, that motivate bringing the past into the present. How does the temporality of memory influence the ways that national pasts and national futures (both past and present conceptions of the future) are remembered and imagined? How are representations of the past and past experiences related to imaginaries of the future? Drawing on the work of historian Reinhart Koselleck (2004), I inquire ask how such 'spaces of experience' that connect past and present link to 'horizons of expectations'? How are they imbued with hope and struggle for change? Sociologist Vikki Bell explains it thus:

The battles about what form modes of remembrance should take implicitly recognize that how the past is organized allows one to embrace the future, not because the past is put to rest, but because that past is collected and organized in a vital way, in a way that guide the future, as the process of justice, education, familial inheritance, and even of cultural pleasure emerge and proceed from the conditions of possibility that the present establishes for them and for these processes, therefore, there is an attention to how political subjectivities of the future are to be given their possibilities. It is a response to the past, one that is driven by responsibility, urged and urgent in the face of the unknown future (Bell 2011: 219).

\section{Conclusion}

Museums are powerful sites of national culture, history, and identity. Official sites and practices profoundly influence the way that citizens understand their nation and the meaning of national belonging. Even as the Salvadoran government has yet to meaningfully commemorate the nation's civil conflict or take action to address its past human rights abuses, other public museums combat this official silence to prevent the public oblivion that can follow.

Theorists of social memory remind us that shared and collective understandings of the past say more about contemporary society and its expectations for the future than they do about any straightforward historical past. Extending that understanding to the dynamic of museums and memory, I agree with Roger Simon (2006), who reminds us that museums as sites of public remembrance are always about the future. By reminding the public about El Salvador's civil conflict and the state violence that occurred, museums can help imagine a future where human rights are protected and defended, and where the bond between state and citizen is one of trust and responsibility. As such, museums in EI Salvador inform narratives that contribute to civic education and civic life and may help build a better society (Letourneau 2004).

With all nations, as I have illustrated in this article, the process by which state and society grapple with a difficult past can be dynamic. Silence in the aftermath of atrocity might be understood for a time, but in a democratizing society such as El Salvador, as it transitions from decades of repressive government, the role of museums in truth-telling and the pursuit of justice is fundamental to imagining a just and inclusive nation.

Received: 8 September 2013

Finally accepted: 14 February 2015 


\section{Notes}

1 The Espacio Memorial de los Derechos Humanos (ex-ESMA) [Memorial Space of Human Rights] transforms the Escuela de Mecanica de la Armada (ESMA) [the Army Mechanic School], a notorious torture center, into a memory space for truth-telling and reflection.

2 Kaji Tulam are words in Quiche, a Maya language. Guatemala has a majority indigenous Maya population, and they received the brunt of the state violence of the protracted civil war.

3 ICMEMO website http://icom.museum/the-committees/international-committees/ international-committee/international-committee-of-memorial-museums-in-remembranceof-the-victims-of-public-crimes/, accessed 18 July 2013.

4 Sites of Conscience website: www.sitesofconscience.org/, accessed 18 July 2013.

5 A complete list of the victim's names can also be found at this website http://www. memoriayverdad.org, accessed 18 July 2013.

6 'Un espacio para la esperanza, para seguir soñando y construir una sociedad mas justa, humana, y equitativa.'

7 My most recent personal conversation with Carlos Henriquez Consalvi was at the Museo de la Palabra y el Imagen on 12 July 2012.

8 This description comes from the exhibit catalog Revisiones: Encuentros en el Arte Salvadoreño, May 18-April 25, 2007, compiled by Jorge Palermo and published by Museo del Arte de El Salvador 2007. Here is the Spanish original: 'históricamente, para mantener relaciones estilísticas y temáticas a lo largo de la ruta para contar la historia de nuestro pueblo y nuestro país reflejada en el arte'.

9 My most recent personal conversation with Roberto Galicia was at MARTE on July 15, 2012.

10 Reflecting the dynamics of the politics of memory, El Salvador's Supreme Court has agreed to review a demand that deems the Amnesty Law unconstitutional. This is motivated in part by international courts that have brought attention to the incompatibility of the Amnesty Law and the commitment to protect human rights.

\section{References}

Anderson, B. (1995) Imagined Communities: Reflections on the Rise and Spread of Nationalism, London: Routledge.

Ashley, S. (2005) 'State Authority and the Public Sphere: Ideas on the Changing Role of Museums as a Canadian Social Institution', Museums and Society, 3(1) 5-17.

Barahona, E.M. et al. (2012) 'Impunidad en El Salvador y Guatemala: "De La Locura a la Esperanza: ¿Nunca Más?”', Impunity in El Salvador and Guatemala. América Latina Hoy, 61, 101-136.

Barrett, J. (2011) Museums and the Public Sphere, Malden, MA: Wiley-Blackwell.

Bell, V. (2011) 'Afterword', In Francesca Lessa and Vincent Druliolle (eds.), The Memory of State Terrorism in the Southern Cone: Argentina, Chile and Uruguay, 209-219, New York: Palgrave-MacMillan. 
Bennett T. (1995) The Birth of the Museum: History, Theory, Politics, London: Routledge.

Bonnell, J. and Simon, R.I. (2007) 'Difficult' Exhibitions and Intimate Encounters. Museum and Society, 5(2) 65-85.

Boswell, D. \& Evans, J. (eds.) (1999) Representing the Nation: A Reader-Histories, Heritage and Museums, London \& New York: Routledge.

Crane, S. (2000) Museums and Memory, Stanford, CA: Stanford University Press.

Duncan, C and Wallach, A. (1980) 'The Universal Survey Museum', Art History, 3(4) 448471.

Estefane, A. (2013) 'Materiality and Politics in Chile's Museum of Memory and Human Rights', Thresholds 41, Spring 2013, 158-17.

Gomez-Barris, M. (2008) Where Memory Dwells: Culture and State Violence in Chile, Berkeley: University of California Press.

Jelin, E. (1994) 'The Politics of Memory: the Human Rights Movement and the Construction of Democracy in Argentina', Latin American Perspectives 21(2) 38-58.

(2002) Los Trabajos de La Memoria, Mexico, DF: Siglo XXI.

Kosseleck, R. (1985) Futures Past: On the Semantics of Historical Time,

Cambridge, MA: MIT Press.

Lazzara, M.J. (2003) 'Tres Recorridos de Villa Grimaldi', in Elizabeth Jelin and and Victoria Langland, (eds) Monumentos, Memorials, y Marcas Territoriales, [PAGE NUMBERS HERE PLEASE], Madrid: Siglo XXI de España Editores.

Lessa, F. and Druliolle, V. (eds.) (2011) The Memory of State Terrorism in the Southern Cone: Argentina, Chile and Uruguay, New York: Palgrave-MacMillan.

Lessa, F. (2011) 'No Hay Que Tener Ojos en la Nuca: The Memory of Violence in Uruguay, 1973-201', in Francesca Lessa and Vincent Druliolle (eds.), The Memory of State Terrorism in the Southern Cone: Argentina, Chile and Uruguay, 179-208, New York: Palgrave-MacMillan.

Létourneau, J. (2004) History for the Future: Writing Memory and Identity in

Quebec, Montreal and Kingston: McGill-Queen's University Press.

Logan, W. and Reeves, K. (2009) Places of Pain and Shame: Dealing with Difficult Heritage, New York: Routledge.

Macdonald, S. and G. Fyfe (eds.) (1996) Theorizing Museums, Oxford: Basil Blackwell.

Mallonee, L.C. (2014a) ‘Guatemala's Indigenous Community Expresses Concern Over New Maya Museum', Hyperallergic, 11 February 2014 http://hyperallergic.com/108233/ guatemalas-indigenous-community-expresses-concern-over-new-maya-museum/, accessed May 30, 2014.

Mallonnee, L.C. (2014b) ‘Creating a National Art in El Salvador', Hyperallergic, 13 March 2014, http://hyperallergic.com/114155/creating-a-national-art-in-el-salvador, accessed 29 May 2014. 
Oleaga, M.G. et al. (2011) 'Looking from Above: Saying and Doing in the History Museums of Latin America', Museum \& Society, 9(1) 49-76.

Passerini, L. (2006) 'Memories between Silence and Oblivion' in K. Hodgkins, S. Radstone (eds.) Memory, History, Nation: Contested Pasts, 238-254. New Brunswick, NJ: Transaction Publishers.

Passerini, L. (2005) 'Amnesty without Amnesia: Book review of Paul Ricoeur's Memory, History, Forgetting', Times Higher Education, October 21, 2005.

http://www.timeshighereducation.co.uk/books/amnesty-without-amnesia/199271.article, accessed 20 July 2013.

Poole, R. (2009) 'Enacting Oblivion', International Journal of Politics, Culture and Society, 22, $149-157$.

Purbrick, L. (2011) 'Museums and the Embodiment of Human Rights', Museums and Society, 9(3) 166-189.

Ricoeur, P. (2004) Memory, History, Forgetting, Chicago: University of Chicago Press.

Roniger, L. and M. Sznajder (1999) The Legacy of Human-Rights Violations in the Southern Cone, Oxford: Oxford University Press.

Ros, A. (2012) The Post-Dictatorship Generation in Argentina, Chile and Uruguay: Collective Memory and Cultural Production, New York: Palgrave MacMillan.

Simon, R. I. (2006) 'Museums, Civic Life, and the Educative Force of Remembrance,' The Journal of Museum Education, 31(2) 113-22.

UN Security Council, Annex (1993) From Madness to Hope: the Twelve-Year Civil War in El Salvador: Report of the Commission on the Truth for El Salvador, S/25500, 1993, 5-8.

Vivian, B. (2010) Public Forgetting: the Rhetoric and Politics of Beginning Again, University Park, PA: Penn State Press.

Williams, P. (2007) Memorial Museums: the Global Rush to Commemorate Atrocities, Oxford: Berg.

Robin Maria DeLugan, PhD is Associate Professor of Anthropology at the University of California-Merced. She is author of Reimagining National Belonging: Post-Civil War El Salvador in a Global Context (University of Arizona Press, 2012).

${ }^{*}$ Robin Maria DeLugan, PhD

Associate Professor of Anthropology

School of Social Sciences, Humanities \& Arts

University of California

5200 N. Lake Road

Merced, CA 95343 USA

rdelugan@ucmerced.edu

(209) 228-4032

(209) 228-4007 